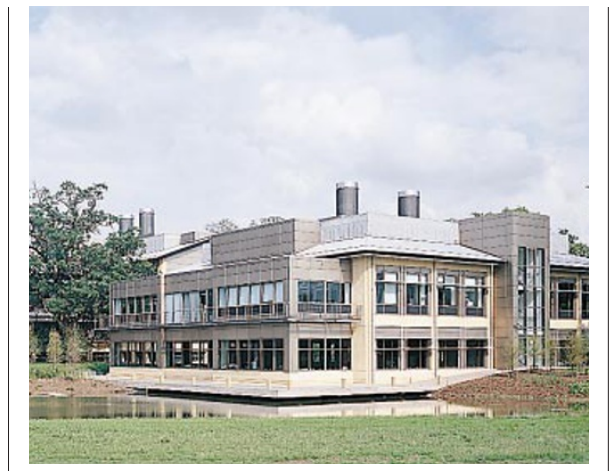

Existing buildings on the Hinxton campus, home of Britain's role in the Human Genome Project.

who supported the council's view. One such witness was Roger Quince, managing director of a nearby science park, Granta Park, and a founder of the technology management consultancy Segal, Quince, Wicksteed. He said the plan presupposes that research at the campus will lead directly to commercialization - the so-called 'linear model'.

Quince pointed out that individuals who were located elsewhere, such as at research departments at the University of Cambridge, hospitals and other businesses, were equally likely to contribute to the development of drugs from genomics.

Despite the absence of quantitative data, the trust had obtained letters of support from senior scientists representing science parks in Israel and the United States, as well as from major pharmaceutical companies.

Support also came from PPL Therapeutics, which in 1992 moved from premises at the University of Edinburgh to offices within 200 metres of the Roslin Institute, home of Dolly, the first cloned sheep. "I am convinced that our extremely successful participation, in what turned out to be a major scientific breakthrough, would not have occurred had we still been five miles down the road in Edinburgh University," wrote Alan Coleman, PPL's research director.

EhsanMasood

\title{
New Howard Hughes head seeks bioinformatics boost
}

[wASHINGTON] The Howard Hughes Medical Institute last week named biochemist Thomas Cech as its next president.

Cech won the Nobel Prize in Chemistry in 1989 for his work on the biocatalytic function of ribonucleic acid. He intends to maintain his laboratory at the University of Colorado at Boulder while running the United States' largest research philanthropy from its headquarters at Chevy Chase, Maryland.

"My two great passions have been biomedical research and science education," Cech says. "This is an opportunity to get involved in these issues at the highest level."

The 51-year-old scientist hopes to see Hughes taking a more active role in applying information technology to biology. "Computing is revolutionizing biology, and we could be at the forefront of bioinformatics," he says. "The institute could support investments in bioinformatics and, for example, set up regional centres" for computing.

Hughes currently spends most of its $\$ 420$ million science programme on directly supporting 318 US investigators, among them many of the country's most accomplished life scientists, including Cech. It also spends $\$ 100$ million each year on a grants programme that supports the reform of lifescience teaching at US universities, as well as researchers outside the United States.

Cech, who has always taught chemistry to first-year students at his own university, is very enthusiastic about the university teaching programme. "It's a real American success story," he says. "Everywhere I go, institutes have been using this money to redefine the way they educate science students."

He seems less sure about the international programmes that support scientists in

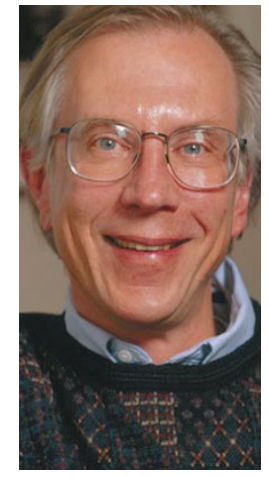

Cech: a passion for science education. Trust, the only medical research philanthropy of comparable size, Cech doesn't expect to follow its example by influencing government research policy.

"Lobbying the government is not on my list of activities," he says. Hughes may, however, raise its profile by becoming more involved in public discussion of the ethical, legal and other issues surrounding science.

The Howard Hughes Medical Institute was set up by the billionaire aviator as a tax dodge in 1953, but was reconstituted after his death. Independent trustees gained control in 1984, sold its main asset, Hughes Aircraft, to General Motors, and reached an agreement with tax authorities that requires it to spend at least 3.5 per cent of its vast endowment on medical research.

The stock-market boom has taken the value of that endowment to more than \$11 billion. Cech will probably become the world's best-paid science administrator next January. His predecessor Purnell Choppin, president since 1987, earned more than $\$ 600,000$ a year.

Colin Macilwain

\section{Scientists welcome Prodi as European Commission president}

[MUNICH] Last week's appointment of former Italian prime minister Romano Prodi as president of the European Commission, following the resignation of his predecessor Jacques Santer, could be good news for Europe's scientific community.

Prodi, a professor of economics at the University of Bologna, is a firm believer in the importance of science to a strong, stable economy (see Nature 375, 620; 1995). As prime minister he oversaw the start of a major review of Italy's science institutions.

Glauco Tocchini-Valentini, director of the Italian National Research Council's Institute of Cell Biology at Monterotondo, says Prodi has always been very sensitive to science.

Enric Banda, general secretary of the
European Science Foundation, calls Prodi "a federalist who believes in promoting cooperation between institutions". He believes that Prodi will be sympathetic to the concept of significant levels of basic research being carried out at European level.

"Fundamental research is certainly seen as a federal issue in the United States," Banda points out. In contrast, basic research has had to fight to maintain its small presence in the European Union's fifth Framework programme (FP5), as it is considered primarily the responsibility of individual member states.

"I'm sure that his appointment as head of the commission must be good for science in the medium term - even if science becomes temporarily swallowed up by other political priorities," says Banda. Such was the fate of the Italian science review, which is only now approaching completion.

Prodi's choice of research commissioner, which should become clear by early summer, will also be important. But as he puts together his new commission over the next month, European scientists need not fear that FP5 project funding will be delayed.

The research commission, foreseeing the possible departure of the commissioners who resigned en bloc following a critical report - ensured that any critical decisions on individual FP5 programmes were taken by early March. Calls for proposals for each of them have now been issued. Alison Abbott 